\title{
Social Patterns
}

in Australian Literature 


\section{BY THE SAME AUTHOR}

PROSE

The Half Way Sun (novel)

Six Australian Poets (criticism)

The Misfortunes of Henry Handel Richardson (monograph)

Rolf Boldrewood (in Great Australians biographical series)

POEMS

Adagio in Blue

Emu Parade

Bayonet and Grass

PLAYS

Love's Revenge (comedy, in Philippine Plays)

We're Going Through (radio verse play)

EDITOR OF

Best Australian One-act Plays (with William Moore)

Australian Poetry 1946

Australia Writes

Selected Poems of Henry Kendall

A Book of Australia

Henry Kendall (Australian Poets Series)

Poetry in Australia, vol. I: From the Ballads to Brennan 


\section{T. Inglis Moore}

\section{SOCIAL \\ PATTERNS \\ IN}

\section{AUSTRALIAN LITERATURE}


UNIVERSITY OF CALIFORNIA PRESS

BERKELEY AND LOS ANGELES, CALIFORNIA

First publisbed in 1971

ISBN: 0-520-01828-I

Library of Congress Catalog Card Number: 71-133027

(C) T. Inglis Moore 1971

PRINTED IN AUSTRALIA 
To my wife, Peace, whose devoted and understanding support has made this book possible, and to my daughter, Pacita Alexander, who helped in times of need. 
